Jurnal Belajar Bahasa, ISSN 2502-5864, E-ISSN 2503-0329

Volume 3, No. 2, September 2018

\title{
PENINGKATAN KETERAMPILAN MENULIS PUISI DENGAN MODEL PEMBELAJARAN QUANTUM TEACHING TIPE TANDUR
}

\author{
Muhammad Syahruzzaki \\ Universitas Muhammadiyah Jember \\ zakikiki307@gmail.com
}

\begin{abstract}
ABSTRAK
Masalah penelitian ini yaitu bagaimanakah model pembelajaran quantum teaching tipe TANDUR dapat meningkatkan keterampilan menulis puisi dan partisipasi siswa dalam pembelajaran kelas VII MTS Miftahul Ulum Curah Takir. Tujuan penelitian ini yaitumendeskripsikan bagaimana model pembelajaran quantum teaching tipe TANDUR dapat meningkatkan keterampilan menulis puisi dan partisipasi siswa dalam pembelajaran kelas VII MTS Miftahul Ulum Curah Takir. Penelitian ini merupakan penelitian tindakan kelas yang dilaksanakan dalam 1 siklus. Teknik yang digunakan dalam penelitian ini berupa tes menulis puisi bagi siswa, dan non-tes berupa observasi, wawancara, dan dokumentasi.Hasil penelitian ini menunjukkan adanya peningkatan keterampilan menulis puisi dengan model pembelajaran quantum teaching tipe TANDUR. Hasil rata-rata nilai dari pre-test yaitu 63,7 , dan hasil rata-rata nilai dari post-test siswa yaitu 86,0 atau meningkat sebesar $35,01 \%$. Dari keseluruhan siswa yang mencapai ketuntasan sebesar 87,5\%. Peningkatan kenterampilan menulis puisi siswa juga diikuti dengan perubahan perilaku, yaitu dengan lebih berpartisipasi aktif dalam mengikuti pembelajaran.
\end{abstract}

Kata Kunci: menulis, puisi, Quantum teaching, TANDUR

\section{ABSTRACT}

Research issues include how the quantum learning model teaching type TANDUR can improve the skills of writing poetry and the students' participation in learning Class VII MTS Miftahul Ulum Bulk Takir. The purpose of the study is to describe how the model of quantum learning teaching type TANDUR can improve the skills of writing poetry and the students' participation in learning Class VII MTS Miftahul Ulum Bulk Takir. This research is an action research conducted a class in 1 cycle. The techniques used in this research in the form of poetry writing test, and non test is in the form of observation, interviews, and documentation. The results of this study showed an increase in the skill of poetry writing with a model of quantum learning teaching type TANDUR. The average value of the pre-test was 63.7, and post-test was 86.0 . It has increased by $35.01 \%$. The overall the students who have completed the minimum passing scores were $87.5 \%$. The improvement of poetry writing skill was also accompanied by a change in behaviour in students' participation. They become more actively participated during the lesson..

Keywords: poetry, Quantum teaching, TANDUR, writing

\section{PENDAHULUAN}

Keterampilan menulis merupakan aspek kebahasaan yang bersifat produktif menghasilkan suatu karya. Keterampilan menulis dalam dunia pendidikan harus dikuasai dan dipahami oleh siswa, bukan hanya sebatas diketahui saja. Siswa akan memiliki kemampuan untuk meng- eskpresikan atau mengungkapkan gagasan (ide), pemikiran, pendapat, dan perasaan yang dimiliki, sehingga daya pikir, imajinasi, dan kreativitas siswa dapat berkembang. Menulis termasuk dalam suatu kegiatan yang produktif dan ekspresif. Kegiatan dalam menulis ini, diharuskan penulis kreatif 

Jurnal Belajar Bahasa, ISSN 2502-5864, E-ISSN 2503-0329

Volume 3, No. 2, September 2018

dalam menggunakan grafologi, struktur bahasa, dan kosa kata(Tarigan, 2013, hal. 3).

Salah satu kegiatan menulis yaitu menulis sastra, seperti menulis puisi. puisi dapat mengembangkan hasil pengolahan pikiran sehingga dapat menemukan hal-hal baru untuk mengungkapkan melalui tulisan berupa teks puisi. Puisi melalui kata-kata yang sederhana tetapi memiliki banyak makna, sehingga tercipta sebuah karya sastra yang indah (Samosir, 2013, hal. 25). Menurut Waluyo puisi merupakan sebuah pengalaman jiwa dan bersifat imajinatif yang diungkapkan melalui pikiran dan perasaan seorang penyair(Suyanto, 2013, hal. 1). Puisi disusun melalui kekuatan bahasa dengan pengonsentrasian struktur fisik dan struktur batinnya.

Standar Kompetensi mata pelajaran bahasa Indonesia aspek bersastra SMP/MTS kelas VII semester 2 dalam aspek menulis yaitu mengungkapkan keindahan alam dan pengalaman melalui kegiatan menulis kreatif puisi. Sedangkan indikator yang harus dicapai yaitu siswa mampu menulis kreatif puisi berkenaan dengan keindahan alam.

Berdasarkan masalah awal yang diperoleh peneliti mengenai keterampilan menulis puisi siswa kelas VII mengalami masalah beberapa pokok. Masalah tersebut yaitu kurangnya minat dan motivasi siswa dalam menulis puisi, siswa berpendapat bahwa menulis puisi adalah sebuah hobi atau bakat, sehingga kemampuan menulis mereka mengalami kesulitan. Selain itu mereka membutuhkan waktu yang lama dalam kegiatan menulis sehingga keterampilan menulis yang mereka miliki kurang malsimal.

Penyebab utama yang perlu dilakukan perbaikan adalah model pembelajaran, dan pengelolaan kelas yang dilakukan oleh guru. Pengelolaan kelas yang baik akan melahirkan interaksi belajar mengajar yang baik pula serta tujuan pembelajaran pun dapat dicapai tanpa menemukan kendala yang berarti(Djamarah \& Zain, 2014, hal. 2).

Berdasarkan hal tersebut, peneliti menerapkan model pembelajaran quantum teaching tipe TANDUR untuk menumbuhkan bermacam-macam inte-raksi yang ada di dalam maupun di luar momen belajar (DePorter, Reardon, \& Nourie, 2010, hal. 34). Berdasarkan penelitian terdahulu bahwa model pembelajaran quantum teaching tipe TANDUR dapat meningkatkan keterampilan menulis puisi (Majid, 2013).

\section{METODE PENELITIAN}

Penelitian ini merupakan penelitian tindakan kelas (PTK) yang merupakan jenis penelitian yang menjelaskan baik proses maupun hasil, yang bertujuan untuk meningkatkan kualitas pembelajaran di kelas (Arikunto, Suhardjono, \& Supardi, 2017, hal. 1). Desain penelitian yang digunakan yaitu desain model Kurt Lewin. Desain Kurt Lewin terdapat satu siklus, akan tetapi memiliki siklus altenatif jika siklus pertama tidak mencapai kriteria kesuksesan. Desain model penelitian tersebut terdiri dari tahap perencanaan, tindakan, pengamatan, dan refleksi. Empat tahap tersebut digunakan secara sistematis dalam proses penelitian dan diterapkan dalam satu siklus.

Subjek penelitian ini adalah siswa kelas VII MTS Miftahul Ulum Curah Takir sedangkan Peneliti memilih siswa kelas VII MTS Miftahul Ulum Curah Takir sebagai subjek penelitian karena berdasarkan observasi langsung dan wawancara langsung dengan guru mata pelajaran bahasa Indonesia, bahwa siswa 

Jurnal Belajar Bahasa, ISSN 2502-5864, E-ISSN 2503-0329

Volume 3, No. 2, September 2018

mengalami kesulitan dalam menemukan ide dalam menulis puisi dan kurangnya motivasi siswa dalam keterampilan menulis puisi, sehingga perlu adanya pembelajaran yang menjadikan siswa lebih tertarik dalam pembelajaran menulis puisi.

Lokasi penelitian yang dilakukan yaitu di MTS Miftahul Ulum Curah Takir. Peneliti memilih lokasi tersebut dengan segala pertimbangan sebagai berikut: (1) pihak sekolah dan guru mata pelajaran bahasa Indonesia mengijinkan dilakukannya penelitian, (2) MTS Miftahul Ulum Curah Takir belum pernah dilakukannya penelitian serupa, dan (3) kurangnya minat siswa dalam pembelajaran menulis puisi, sehingga peneliti tertarik untuk mengembangkan minat siswa terhadap pembelajaran menulis puisi.

Pengumpulan data dalam penelitian ini menggunakan teknik observasi, teknik tes, teknik wawancara, dan teknik dokumentasi. Instrumen yang dinggunakan yaitu pedoman observasi, alat tes, pedoman wawacara, dan dokumentasi.

\section{PEMBAHASAN}

Luxemberg menyatakan bahwa puisi merupakan sebuah karya seni yang diciptakan secara kreatif (Wardoyo, 2013, hal. 13). Sementara itu, pendapat dari Santoso menyatakan bahwa puisi merupakan sebuah ekpresi kepribadian dengan suatu bentuk yang tepat dan selaras melalui penggunaan kebahasaan yang dipilih dengan semurni-murninya(Suyanto, 2013, hal. 19). Ragam karya sastra ini pada awalnya harus mengikuti bahasa yang telah ditentukan seperti irama, matra, rima, dan tata bahasa lainnya. Adanya perkembangan selanjutnya terjadi penyimpangan dari aturan tersebut seperti, puisi konkret, puisi kontemporer, dan puisi naratif.

Puisi merupakan bentuk karya sastra yang memiliki dua unsur pokok, yaitu struktur fisik dan struktur batin. Unsur-unsur tersebut membentuk makna yang totalitas secara utuh dan tidak dapat dipisahkan karena memiliki keterakitan yang erat antar satu dengan lainnya (Wardoyo, 2013, hal. 23).

Hasil penelitian ini terdapat hasil tes dan nontes. Hasil tes ini berupa hasil tes keterampilan menulis puisi dengan model pembelajaran quantum teaching tipe TANDUR. Sedangkan hasil nontes berupa hasil observasi, wawancara, dan dokumentasi pada saat pelaksanaan tindakan.

Hasil tes dari menulis puisi ini didasarkan dari empat aspek yang harus diperhatikan dalam menulis puisi. Keempat aspek tersebut yaitu: (1) kesesuaian isi dengan tema, (2) diksi, (3) rima, (4) tipografi. Jumlah siswa yang mengikuti tes sebanyak 24 siswa. Hasil tes siswa menulis puisi dengan model pembelajaran quantum teaching tipe TANDUR memiliki rata-rata 86,09. Jumlah siswa yang memperoleh nilai di bawah 75 atau kurang dari KKM hanya terdapat 3 siswa, hal tersebut dikarenakan kurang memperhatikannya siswa tersebut dengan penjelasan dari guru, sehingga kesulitan dalam menulis puisi.

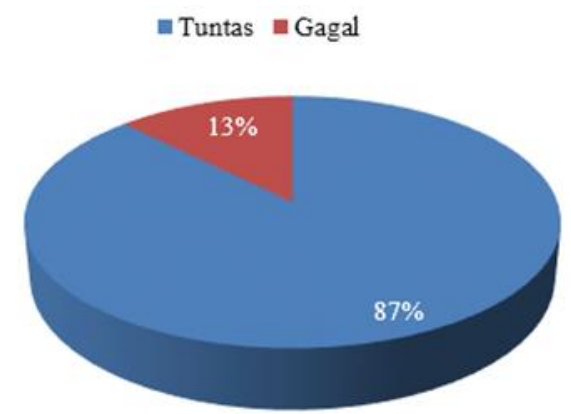

Gambar 1. Jumlah Ketuntasan Tes Keterampilan Menulis Puisi 

Jurnal Belajar Bahasa, ISSN 2502-5864, E-ISSN 2503-0329

Volume 3, No. 2, September 2018

Gambar 1 menunjukkan jumlah siswa yang mencapai ketuntasan dalam hasil tes keterampilan menulis puisi pada saat pelaksanaan tindakan. Berdasarkan diagram di atas, presentase siswa yang tuntas dalam tes menulis puisi mencapai $87 \%$ atau sebanyak 21 siswa, sedangkan presentase siswa yang kurang mencapai ketuntasan atau gagal yaitu $13 \%$ atau sebanyak 3 siswa. Penilain pada hasil tes siswa ditentukan melalui setiap aspek yang ditentukan, nilai aspek dapat dilihat pada tabel 1 berikut.

Data tabel 1 menunjukkan nilai rata-rata keterampilan menulis puisi pada setiap aspek. Skor rata-rata aspek meliputi: aspek kesesuaian isi dengan tema mencapai skor rata-rata 95,8, aspek diksi mencapai skor rata-rata 81,6 , aspek rima mencapai skor rata-rata 85 , dan aspek tipografi mencapai skor rata-rata 77,5 .

Tabel 1. Nilai Rata-rata Siswa pada Tiap Aspek

\begin{tabular}{clc}
\hline No. & Aspek yang dinilai & $\begin{array}{c}\text { Skor Rata- } \\
\text { rata }\end{array}$ \\
\hline 1. & Kesesuaian isi dengan & 95,8 \\
2. & tema & \\
3. & Rimsi & 81,6 \\
4. & Tipografi & 85 \\
\hline
\end{tabular}

Tabel 2. Hasil Tes Menulis Puisi Aspek Kesesuaian Isi dengan Tema

\begin{tabular}{cccc}
\hline No & $\begin{array}{c}\text { Skor } \\
\text { Penilaian }\end{array}$ & Frekuensi & $\begin{array}{c}\text { Bobot } \\
\text { skor }\end{array}$ \\
\hline 1. & 15 & 19 & 285 \\
2. & 12 & 5 & 60 \\
3. & 9 & 0 & 0 \\
4. & 6 & 0 & 0 \\
5. & 3 & 0 & 0 \\
\hline & & 24 & 345 \\
\hline
\end{tabular}

Hasil keseluruhan dan pembahasan pada setiap aspek dapat dilihat pada tabel berikut ini.

\section{a. Aspek Kesesuaian Isi dengan Tema}

Tema merupakangagasan utama atau ide yang mewakili keseluruhan pokok persoalanyang dituangkan oleh penyair dalam puisinya(Samosir, 2013, hal. 25). Penilaian aspek kesesuaian isi dengan tema difokuskan pada penggunaan tema yang menarik, menggambarkan isi, mempunyai makna, dan lugas. Hasil penelitian tes pada aspek kesesuaian isi dengan tema dapat dilihat pada tabel 2.

Data pada tabel 2 menunjukkan skor ratarata yang dicapai siswa dalam aspek kesesuaian isi dengan tema pada pelaksanaan tindakan 95,8. Terdapat 19 siswa yang memperoleh skor 15 , dan 5 siswa dengan skor 12. Tidak ada siswa yang memperoleh skor 9, 6, dan 3.

\section{b. Aspek Diksi}

Esensi dalam penulisan puisi yaitu pemilihan diksi atau kata, karena diksi merupakan dasar bangunan setiap puisi sedangkan tolak ukur seorang penyair mengenai seberapa jauh daya ciptanya yang asli dapat dilihat dari diksi yang digunakan (Wardoyo, 2013, hal. 23).

Tabel 3. Hasil Tes Menulis Puisi Aspek Diksi

\begin{tabular}{cccc}
\hline & $\begin{array}{c}\text { Skor } \\
\text { Penilaian }\end{array}$ & Frekuensi & Bobot skor \\
\hline 1. & 15 & 5 & 75 \\
2. & 12 & 16 & 192 \\
3. & 9 & 3 & 27 \\
4. & 6 & 0 & 0 \\
5. & 3 & 0 & 0 \\
\hline & & 24 & 294 \\
\hline
\end{tabular}


Muhammad Syahruzzaki. Peningkatan Keterampilan Menulis Puisi ... Jurnal Belajar Bahasa, ISSN 2502-5864, E-ISSN 2503-0329

Volume 3, No. 2, September 2018

Penilaian aspek diksi didasarkan pada penggunaan kata yang bervariasi, pemadatan bahasa, sarana retorika, dan penggambaran isi. Hasil penelitian tes pada aspek diksi dapat dilihat pada tabel 3 berikut.

Data tabel 3 menunjukkan skor rata-rata yang dicapai siswa dalam aspek diksi yaitu 81,6 . Terdapat 5 siswa yang memiliki skor tinggi yaitu 15, 16 siswa dengan skor 12, dan 3 siswa mendapatkan skor 9 . Tidak ada siswa yang medapatkan skor 6 dan 3 .

\section{c. Aspek Rima}

Penilaian pada aspek rima berdasarkan penggunaan rima yang bervariasi. Hasil penelitian tes pada aspek rima dapat dilihat pada tabel 4 berikut.

Data pada tabel 4 tersebut menunjukkan bahwa rata-rata skor dalam aspek rima yang dicapai siswa sebesar 85. Terdapat 8 siswa yang memperoleh skor tertinggi yaitu 10, 14 siswa dengan skor 8, dan 2 siswa memperoleh skor 6 . Siswa tidak ada yang memperoleh skor 4 dan 2.

\section{d. Aspek Tipografi}

Penilaian pada aspek tipografi berdasarkan bagaimana bentuk visualisasi yang menarik, dapat memperjelas makna, menciptakan suasana, dan menunjukkan sebuah ide atau gagasan. Hasil penelitian aspek tipografi dapat dilihat pada tabel 5 berikut.

Tabel 4. Hasil Tes Menulis Puisi Aspek Rima

\begin{tabular}{cccc}
\hline No & $\begin{array}{c}\text { Skor } \\
\text { Penilaian }\end{array}$ & Frekuensi & Bobot skor \\
\hline 1. & 10 & 8 & 80 \\
2. & 8 & 14 & 112 \\
3. & 6 & 2 & 12 \\
4. & 4 & 0 & 0 \\
5. & 2 & 0 & 0 \\
\hline & & 24 & 204
\end{tabular}

Tabel 5. Hasil Tes Menulis Puisi Aspek Tipografi

\begin{tabular}{cccc}
\hline No & $\begin{array}{c}\text { Skor } \\
\text { Penilaian }\end{array}$ & Frekuensi & $\begin{array}{c}\text { Bobot } \\
\text { skor }\end{array}$ \\
\hline 1. & 10 & 3 & 30 \\
2. & 8 & 15 & 120 \\
3. & 6 & 6 & 36 \\
4. & 4 & 0 & 0 \\
5. & 2 & 0 & 0 \\
\hline & & 24 & 186 \\
\hline
\end{tabular}

Data pada tabel 5 tersebut menunjukkan bahwa rata-rata skor dalam aspek tipografi yang dicapai siswa sebesar 77,5 . Terdapat 3 siswa yang memperoleh skor tertinggi yaitu 10, 15 siswa yang memperoleh skor 8, dan 6 siswa dengan skor 6. Siswa tidak ada yang memperoleh skor 4 dan 2 .

Hasil nontes diperoleh melalui observasi, wawancara, dan dokumentasi foto. Hasil nontes diuraikan sebagai berikut.

\section{a. Hasil Observasi}

Observasi dilakukan selama proses pembelajaran berlangsung. Observasi dilakukan oleh peneliti dan dibantu teman sejawat. Pengambilan data observasi ini bertujuan untuk melihat perilaku siswa dalam menerima atau mengikuti pembelajaran menulis puisi dengan model pembelajawan quantum teaching tipe TANDUR. Melalui observasi ini peneliti dapat mendeskripsikan beberapa perilaku siswa selama mengikuti pembelajaran menulis puisi dengan model pembelajawan quantum teaching tipe TANDUR.

Objek yang diamati antara lain: (1) perhatian siswa terhadap penjelasan guru, (2) siswa yang aktif tanya jawab dengan guru, (3) siswa yang antusias dalam pembelajaran menulis puisi, (4) siswa yang aktif menulis puisi dengan media benda nyata (the real things media), dan (5) siswa 

Jurnal Belajar Bahasa, ISSN 2502-5864, E-ISSN 2503-0329

Volume 3, No. 2, September 2018

secara tertib dan teratur mengumpulkan hasil karyanya. Perolehan nilai sebagai hasil observasi atau pengamatan terhadap perilaku siswa kelas VII selama pembelajaran menulis puisi dengan model pembelajaran quantum teaching tipe TANDUR akan disajikan dalam bentuk tabel 6 berikut.

Tabel 6. Perolehan Nilai Hasil Observasi Perilaku Positif

Perilaku Positif

\begin{tabular}{|c|c|c|c|}
\hline No. & Aspek yang dinilai & Frekuensi & $\begin{array}{c}\text { Persen } \\
\text { (\%) }\end{array}$ \\
\hline 1. & $\begin{array}{l}\text { Perhatian siswa } \\
\text { terhadap } \\
\text { penjelasan guru }\end{array}$ & 20 & $83,3 \%$ \\
\hline 2. & $\begin{array}{l}\text { Siswa yang aktif } \\
\text { tanya jawab } \\
\text { dengan guru }\end{array}$ & 19 & $79,1 \%$ \\
\hline 3. & $\begin{array}{l}\text { Siswa yang } \\
\text { antusias dalam } \\
\text { pembelajaran } \\
\text { menulis puisi } \\
\text { dengan model } \\
\text { pembelajaran } \\
\text { quantum teaching } \\
\text { tipe TANDUR. }\end{array}$ & 20 & $83,3 \%$ \\
\hline 4. & $\begin{array}{l}\text { Siswa yang aktif } \\
\text { menulis puisi } \\
\text { dengan media } \\
\text { benda nyata (the } \\
\text { real thing media) }\end{array}$ & 22 & $91,6 \%$ \\
\hline 5. & $\begin{array}{l}\text { Siswa secara } \\
\text { tertib dan teratur } \\
\text { mengumpulkan } \\
\text { hasil karyanya }\end{array}$ & 20 & $83,3 \%$ \\
\hline
\end{tabular}

Berdasarkan tabel 6 dapat dilihat bahwa selama dilaksanakan pembelajaran menulis puisi dengan model pembelajaran quantum teaching tipe TANDUR siswa dapat mengikuti pembelajaran dengan baik. Aspek pertama dalam observasi ini yaitu perhatian siswa terhadap penjelasan guru. Siswa yang berperilaku positif dengan jumlah 20 atau sebesar $83,3 \%$ siswa memperhatikan dengan serius saat guru menyampaikan materi pembelajaran menulis puisi.

Aspek kedua yaitu keaktifan siswa dalam kegiatan tanya jawab dengan guru. Siswa yang menunjukkan perilaku positif 19 siswa atau sebesar $79,1 \%$. Siswa aktif dalam menjawab pertanyaan yang diberikan guru dan siswa tidak malu untuk bertanya ketika mengalami kesulitan dalam menulis puisi menggunakan media benda nyata.

Aspek ketiga yaitu antusias siswa dalam mengikuti pembelajaran menulis puisi dengan model pembelajaran quantum teaching tipe TANDUR. Siswa yang berperilaku positif 20 siswa atau sebesar $83,3 \%$. Berdasarkan hasil pengamatan siswa antusias mengikuti pembelajaran karena pembelajaran menulis puisi dengan model pembelajaran quantum teaching tipe TANDUR menggunakan media benda nyata menyenangkan dan tidak membosankan.

Aspek keempat yaitu siswa aktif dalam menulis puisi melalui media benda nyata (The real things media). Siswa yang menunjukkan perilaku positif 22 siswa atau sebesar 91,6\%. siswa aktif dalam mengamati benda yang akan ditulis menjadi puisi dan siswa menulis puisi dengan sungguhsungguh.

Aspek kelima yaitu ketertiban dan keteraturan siswa dalam mengumpulkan tugas hasil karyanya. Siswa yang menunjukkan perilaku positif 20 siswa atau sebesar $83,3 \%$, siswa menata lembaran hasil tulisannya dengan rapi, tidak gaduh atau ribut, dan mengumpulkan dari waktu yang sudah ditentukan. Hal ini membuktikan siswa mengumpulkan tugas secara tertib dan teratur. 
Jurnal Belajar Bahasa, ISSN 2502-5864, E-ISSN 2503-0329

Volume 3, No. 2, September 2018

Tabel 7. Perolehan Nilai Hasil Observasi

Perilaku Negatif

Perilaku Negatif

No.

Aspek yang dinilai Frekuensi

Persen

(\%)

1. Siswa tidak

memperhatikan

penjelasan guru

2. Siswa tidak aktif tanya jawab dengan guru

3. Siswa tidak antusias dalam pembelajaran menulis puisi dengan model pembelajaran quantum teaching tipe TANDUR.

4. Siswa tidak aktif dalam menulis puisi dengan media benda nyata (the real thing media)

5. Siswa tidak mengumpulkan tugas secara tertib dan teratur

Berdasarkan tabel 7 dapat menunjukkan beberapa perilaku negatif siswa. Aspek pertama siswa yang tidak memperhatikan penjelasan guru berjumlah 4 siswa atau sebesar $16,6 \%$. Siswa tersebut tidak serius memperhatikan penjelasan dari guru karena berbicara dengan temannya, melamun, dan bermalas-malasan.

Aspek kedua yaitu siswa yang tidak aktif dalam kegiatan tanya jawab dengan guru berjumlah 5 siswa atau 20,8\%. Siswa tersebut tidak percaya diri untuk menjawab pertanyaan dari guru karena siswa takut jawabannya salah, siswa merasa malu untuk bertanya kesulitan yang dialami dalam pembelajaran, terdapat siswa yang acuh tak acuh saat pembelajaran sehingga tidak bisa menjawab pertanyaan dari guru.

Aspek ketiga yaitu siswa yang tidak antusias dalam pembelajaran menulis puisi berjumlah 4 siswa atau 16,6\%. Siswa tidak antusias dan serius dalam memperhatikan penjelasan guru. Saat guru memberikan motivasi terhadap siswa justru mereka tidak memperhatikan, bermalas-malasan, berbicara dengan teman.

Aspek keempat yaitu siswa yang tidak aktif dalam menulis puisi berjumlah 2 siswa atau $8,3 \%$. Menulis puisi dilakukan dengan tidak serius dan bersungguh-sungguh, masih bercanda bersama teman. Aspek terakhir dari observasi yaitu siswa yang tidak tertib dan teratur dalam mengumpulkan tugas yang diberikan guru yaitu hasil karya puisinya. terdapat 4 siswa atau $16,6 \%$ yang tidak mengumpulkan tugas dengan tepat waktu yang ditentukan oleh guru.

Berdasarkan pengecekan hasil dari pengamatan atau observasi yang telah dilakukan oleh peneliti, dan guru mengenai partisipasi siswa dalam pembelajaran menulis puisi lebih baik dari pada sebelum dilakukan tindakan kelas. Hal tersebut dapat diketahui melalui 20 siswa atau lebih yang mulai berperilaku positif, sesuai dengan kriteria kesuksesan yang ditentukan. Terdapat aspek perilaku yang belum mencapai kriteria kesuksesan yaitu siswa yang aktif dalam pembelajaran menulis puisi masih kurang dari 20 siswa. Tetapi guru berpendapat bahwa jumlahsiswa yang aktif mulai meningkat dari sebelum dilakukan tindakan. Berkurangnya perilaku negatif siswa dalam pembelajaran membuktikan adanya perubahan perilaku siswa ke arah 

Jurnal Belajar Bahasa, ISSN 2502-5864, E-ISSN 2503-0329

Volume 3, No. 2, September 2018

yang lebih baik. Perubahan ini menimbulkan kondisi kelas yang lebih kondusif sehingga pembelajaran dapat berlangsung dengan baik.

\section{b. Hasil Wawancara}

Wawancara dilakukan pada tiga siswa yang mendapatkan nilai tinggi, rendah, dan sedang. Wawancara dilakukan pada hari berikutnya yang mengungkapkan 5 pertanyaan sebagai berikut: (1) apakah anda sudah mengerti sebelumnya mengenai model pembelajaran quantum teaching tipe TANDUR?, (2) apakah anda dapat memahami penjelasan dari guru dalam pembelajaran menulis puisi?, (3) apakah anda mengalami kesulitan dalam menulis puisi dengan model pembelajaran quantum teaching tipe TANDUR dan melalui media benda nyata (the real things media)?, (4) bagaimana perasaan anda setelah mengikuti pembelajaran menulis puisi dengan model pembelajaran quantum teaching tipe TANDUR dan melalui media benda nyata (the real things media)?, (5) bagaimana saran anda mengenai pembelajaran menulis puisi dengan model pembelajaran quantum teaching tipe TANDUR dan melalui media benda nyata (the real things media)?

Hasil wawancara jawaban ketiga siswa diketahui mengenai pembelajaran menulis puisi dengan model pembelajaran quantum teaching tipe TANDUR setelah dilakukan pembelajaran menulis puisi siswa lebih memahami bagaimana cara menulis puisi dengan menggunakan media benda nyata. Penggunaan media benda nyata (The Real Things Media) memudahkan siswa untuk menemukan ide, dan diksi yang tepat untuk menulis puisi.

Tanggapan ketiga siswa terhadap penjelasan materi yang diberikan guru dalam pembelajaran menulis puisi mengungkapkan hal yang sama, yaitu penjelasan guru sudah jelas, mudah dimengerti, mudah dipahami, dan tidak membosankan. Mengenai kesulitan yang diperoleh siswa dalam menulis puisi yaitu siswa yang mendapatkan nilai tinggi tidak mengalami kesulitan karena menulis puisi dengan dihadapkan langsung pada media benda nyata, sehingga memudahkan untuk menemukan ide, dan diksi untuk menulis puisi. Siswa yang mendapat nilai sedang dan rendah mengungkapkan dengan adanya media benda nyata sudah cukup membantu menulis puisi sehingga kesulitan yang dialami dapat teratasi.

Siswa mengungkapkan manfaat yang diperoleh dalam menulis puisi dengan model pembelajaran quantum teaching tipe TANDUR dan menggunakan media benda nyata (The Real Things Media) ini membantu mereka dalam menulis puisi, memudahkan untuk menemukan ide, dan diksi menulis puisi, serta pembelajaran yang menyenangkan. Mengenai perasaan setelah dilakukan pembelajaran menulis puisi dengan model pembelajaran quantum teaching tipe TANDUR dan menggunakan media benda nyata (the real things media), siswa yang memiliki nilai tinggi, sedang dan rendah mengungkapkan perasaan yang senang dann bahagia karena dapat belajar menulis puisi dengan cara mengasyikkan dan adanya penghargaan bagi siswa yang aktif dalam pembelajaran.

Saran yang diungkapkan oleh siswa terhadap pembelajaran menulis puisi dengan model pembelajaran quantum teaching tipe TANDUR dan menggunakan media benda nyata (The Real Things Media) yaitu pembelajaran ini seharusnya digunakan 

Jurnal Belajar Bahasa, ISSN 2502-5864, E-ISSN 2503-0329

Volume 3, No. 2, September 2018

dalam pembelajaran mata pelajaran lainnya, tidak hanya dalam pembelajaran menulis puisi.

Berdasarkan hasil wawancara dapat disimpulkan pembelajaran menulis puisi dengan model pembelajaran quantum teaching tipe TANDUR ini mendapat respon yang baik dari siswa. Mengenai penggunaan media benda nyata (The Real Things Media) ini dapat membantu siswa menemukan ide, dan diksi dalam menulis puisi. Penjelasan materi dari guru pun mendapat respon yang baik dari siswa, guru menerangkan materi dengan jelas sehingga dapat dipahami, tidak ada suasana tegang melainkan menyenangkan sehingga pembelajaran berjalan dengan kondusif.

\section{c. Hasil Dokumentasi}

Dokumentasi foto dilakukan pada saat kegiatan proses pembelajaran menulis puisi berlangsung. Dokumentasi foto ini sebagai bukti visual kegiatan pembelajaran selama pelaksanaan atau penelitian tindakan kelas berlangsung.

Berdasarkan hasil tes dan nontes siswa dalam pembelajaran menulis puisi dengan model pembelajaran quantum teaching tipe TANDUR secara keseluruhan menunjukkan bahwa siswa tertarik dengan pembelajaran menulis puisi. Penggunaan media benda nyata (The Real Things Media) yang digunakan memudahkan siswa dalam menulis puisi, dan pembelajaran seperti ini menjadi pengalaman pertama bagi siswa dalam menulis puisi. Pembelajaran yang menyenangkan dan tidak menegangkan membuat siswa lebih mudah menerima pembelajaran karena siswa tidak merasa tertekan dalam pembelajaran. Siswa diberi kebebasan dalam berekspresi dengan apa yang mereka ingin dan menurut mereka mengasyikkan untuk dijadikan sebuah puisi. Berdasarkan hasil tes dan nontes yang telah dicapai oleh siswa selama pembelajaran menulis puisi tersebut telah berhasil maka tidak perlu dilakukan pelaksanaan siklus berikutnya. Hal tersebut sesuai dengan hasil penelitian milik Majid (Majid, 2013)dan Nugroho (Nugroho, 2013)bahwa model pembelajaran quantum teaching tipe TANDUR dapat meningkatkan keterampilan menulis puisi.

\section{SIMPULAN}

Model pembelajaran quantum teaching tipe TANDUR dapat meningkatkan keterampilan menulis puisi siswa, terutama peningkatan pasrtisipasi. Dengan demikian, metode ini direkomendasikan digunakan dalam pembelajaran menulis puisi untuk siswa SMP.

\section{DAFTAR RUJUKAN}

Arikunto, S., Suhardjono, \& Supardi. (2017). Penelitian Tindakan Kelas. Jakarta: Bumi Aksara.

DePorter, B., Reardon, M., \& Nourie, S. S. (2010). Quantum Teaching: Mempraktikkan Qauantum Learning di Ruang-ruang Kelas. Bandung: Kaifa.

Djamarah, S. B., \& Zain, A. (2014). Strategi Belajar Mengajar. Jakarta: PT Rineka Cipta.

Majid, M. Z. (2013). Peningkatan Keterampilan Menulis Puisi Melalui Model Pembelajaran Quantum Teaching Tipe TANDUR. JPBSI, 2 (1): 1-8.

Nugroho, B. A. (2013). Keefektifan Pembelajaran Menulis Puisi Dengan Menggunakan Model Pembelajaran Kuantum Teknik 'TANDUR' Dan Teknik 
Muhammad Syahruzzaki. Peningkatan Keterampilan Menulis Puisi ... $\quad$ Halaman 220 - 229 Jurnal Belajar Bahasa, ISSN 2502-5864, E-ISSN 2503-0329

Volume 3, No. 2, September 2018

'AMBAK' Pada Peserta Didik Smp (RSBI

Dan Non-RSBI). Seloka, 2 (1): 49-53.

Samosir, T. (2013). Apresiasi Puisi. Bandung:

Yrama Widya.

Suyanto. (2013). Mengarang dan Mengapre- siasi Puisi. Surakarta: Yuma Pustaka.

Tarigan, H. G. (2013). Menulis Sebagai Suatu Keterampilan Berbahasa. Bandung: Angkasa.

Wardoyo, S. M. (2013). Teknik Menulis Puisi. Yogyakarta: Graha IImu. 